
Indonesia

\title{
IMPLEMENTASI PENDIDIKAN KARAKTER PADA ANAK USIA DINI
}

\author{
Cucum Novianti* \\ IAI Bunga Bangsa Cirebon
}

email: cucum.noviyanti@gmail.com

\begin{abstract}
- Received: 21 Oktober •Accepted: 26 November •Published online: 1 Desember 2020 2020 2020
\end{abstract}

\begin{abstract}
:
Pendidikan mempunyai peran yang sangat strategis dalam meningkatkan kualitas sumber daya manusia, dan upaya mewujudkan cita-cita bangsa Indonesia dalam mewujudkan kesejahteraan umum dan mencerdaskan kehidupan bangsa. Tujuan pendidikan nasional serta sabda Rasul di atas berbanding lurus bahwa keduanya mempunyai tujuan yang sama dalam membentuk karakter atau akhlak manusia yang mulia. Jadi bisa disimpulkan bahwa karakter itu erat kaitannya dengan personality. Seseorang bisa dikatakan berkarakter apabila tingkah lakunya sesuai dengan kaidah moral. Lembaga pendidikan mempunyai peran yang sangat penting dalam upaya untuk membentuk karakter. Sehingga dalam paper ini dimaksudkan untuk menjabarkan terkait implementasi pendidikan karakter pada anak usia dini.
\end{abstract}

Kata kunci: Impelentasi, Pendidikan, Karakter, Anak Usia Dini

\section{Abstract}

Education has a very strategic role in improving the quality of human resources, and efforts to realize the aspirations of the Indonesian people in realizing general welfare and educating the nation's life. The objectives of national education and the words of the Prophet above are directly proportional to the fact that both have the same goal in shaping noble human character or morals. So it can be concluded that character is closely related to personality. A person can be said to have character if their behavior is in accordance with moral principles. Educational institutions have a very important role in the effort to shape character. So that this paper is intended to describe the implementation of character education in early childhood.

Keywords: Implementation, Education, Character, Early Childhood

\section{A. PENDAHULUAN}

Pendidikan merupakan usaha sadar yang teratur dan sistematis, yang dilakukan oleh orang-orang yang diserahi tanggung jawab untuk mempengaruhi

\footnotetext{
${ }^{*}$ Corresponding Author, Email: cucum.noviyanti@gmail.com
} 


\section{Cucum Novianti}

anak agar mempunyai sifat dan tabiat sesuai cita-cita pendidikan. Pendidikan sebagai tuntutan diartikan pendidikan merupakan suatu yang harus dimiliki oleh setiap manusia tanpa terkecuali di manapun dan kapan pun ia berada. Lebih lagi bagi orang yang berpendidikan di dalam suatu kelompok masyarakat akan dihormati, dihargai serta diambil panutan baginya, hal ini sejalan dengan firman Allah yaitu Al-Qur'an menjelaskan bahwa orang yang mempunyai wawasan ilmu pengetahuan yang didapatkan melalui proses pendidikan mempunyai kedudukan yang tinggi disisi Allah SWT sebagaimana firman-Nya dalam surat al-Mujadilah ayat 11 yang artinya:

Hai orang-orang beriman apabila kamu dikatakan kepadamu: "Berlapang-lapanglah dalam majlis", Maka lapangkanlah niscaya Allah akan memberi kelapangan untukmu. dan apabila dikatakan: "Berdirilah kamu", Maka berdirilah, niscaya Allah akan meninggikan orang-orang yang beriman di antaramu dan orang-orang yang diberi ilmu pengetahuan beberapa derajat. dan Allah Maha mengetahui apa yang kamu kerjakan.

Pendidikan mempunyai peran yang sangat strategis dalam meningkatkan kualitas sumber daya manusia, dan upaya mewujudkan cita-cita bangsa Indonesia dalam mewujudkan kesejahteraan umum dan mencerdaskan kehidupan bangsa. Kebijakan tentang pendidikan telah dirumuskan dalam Undang-Undang Republik Indonesia No 20 tahun 2003 tentang Sistem Pendidikan Nasional yang menjelaskan bahwa tujuan dan fungsi pendidikan adalah sebagai berikut : Pendidikan membentuk watak serta peradaban bangsa yang bermartabat dalam rangka mencerdaskan kehidupan bangsa, bertujuan untuk berkembangnya potensi peserta didik agar menjadi manusia yang beriman dan bertakwa kepada Tuhan Yang Maha Esa, berakhlak mulia, sehat, berilmu, cakap, kreatif, mandiri, dan menjadi warga negara yang demokratis serta bertanggungjawab. (Pasal 3 UU RI No 20/2003).

Rasulullah saw bersabda dalam suatu kesempatan bahwa beliau diutus hanya sanya untuk menyempurnakan akhlak, yang berbunyi :

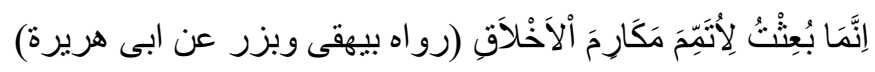

Artinya :

Sesungguhnya aku diutus untuk menyempurnakan akhlak (H.R. Baihaqi dan Abu Dzar dari Abu Hurairoh) 


\section{Cucum Novianti}

Tujuan pendidikan nasional serta sabda Rasul di atas berbanding lurus bahwa keduanya mempunyai tujuan yang sama dalam membentuk karakter atau akhlak manusia yang mulia. Dengan demikian dalam membentuk watak karakter yang baik merupakan suatu hal yang fundamental dalam seluruh lini kehidupan baik itu bermasyarakat, berbangsa maupun dalam beragama. Jadi sudah sangat jelas dalam mewujudkan tujuan pendidikan Nasional, pada segi menjadikan manusia yang berakhlak mulia peran pendidikan yang menjurus pada penanaman aqidah dan akhlak yang baik merupakan suatu yang fundamental.

Secara umum esensi Hadits Nabi di atas dan dalam mewujudkan tujuan pendidikan Nasional bermuatan pendidikan karakter. Pengertian Pendidikan karakter adalah suatu sistem penanaman nilai-nilai karakter kepada warga sekolah yang meliputi komponen pengetahuan, kesadaran atau kemauan, dan tindakan untuk melaksanakan nilai-nilai tersebut, baik terhadap Tuhan Yang Maha Esa (YME), diri sendiri, sesama, lingkungan, maupun kebangsaan sehingga menjadi manusia (insan) kamil. ( Akhmad Sudrajat, Pendidikan Karakter 2017)

Pendidikan karakter bertujuan untuk meningkatkan mutu penyelenggaraan dan hasil pendidikan di sekolah yang mengarah pada pencapaian pembentukan karakter dan akhlak mulia peserta didik secara utuh, terpadu, dan seimbang, sesuai standar kompetensi lulusan. Pendidikan karakter seharusnya membawa peserta didik ke pengenalan nilai secara kognitif, penghayatan nilai secara afektif, dan akhirnya ke pengamalan nilai secara nyata. (Mochtar Bukhori. 2007)

Pendidikan karakter pada tingkatan institusi mengarah pada pembentukan budaya sekolah, yaitu nilai-nilai yang melandasi perilaku, tradisi, kebiasaan keseharian, dan simbol-simbol yang di praktikkan oleh semua warga sekolah, dan masyarakat sekitar sekolah. Permasalahannya, pendidikan karakter di sekolah selama ini baru menyentuh pada tingkatan pengenalan norma atau nilai-nilai, dan belum pada tingkatan internalisasi dan tindakan nyata dalam kehidupan sehari-hari. ( Akhmad Sudrajat, Pendidikan Karakter 2017)

Berdasarkan penelitian di Harvard University Amerika Serikat, ternyata kesuksesan seseorang tidak ditentukan semata-mata oleh pengetahuan dan kemampuan teknis (hard skill) saja, tetapi lebih oleh kemampuan mengelola diri dan orang lain (soft skill) ( Ali Ibrahim 2017) Penelitian ini mengungkapkan, kesuksesan 


\section{Cucum Novianti}

hanya ditentukan sekitar 20 persen oleh hard skill dan sisanya 80 persen oleh soft skill. Bahkan orang-orang tersukses di dunia bisa berhasil dikarenakan lebih banyak didukung kemampuan soft skill daripada hard skill. ( Ahmad Sudrajat 2017) Hal ini mengisyaratkan bahwa mutu pendidikan karakter peserta didik sangat penting untuk ditingkatkan.

\section{B. HASIL DAN PEMBAHASAN}

\section{Pengertian Karakter}

Istilah karakter berasal dari bahasa Yunani, charassein yang berarti mengukir. Membentuk karakter diibaratkan seperti mengukir di atas batu permata atau permukaan besi yang keras. Dari sini kemudian berkembang pengertian karakter yang diartikan sebagai tanda khusus atau pola perilaku. Doni Koesoema A (2007:80) memahami bahwa karakter adalah sama dengan kepribadian. Kepribadian dianggap sebagai ciri atau karakteristik yang bersifat khas dari seseorang yang bersumber dari hasil bentukan-bentukan yang diterima dari lingkungan. Menurut Pusat Bahasa Depdiknas, pengertian karakter adalah bawaan, hati, jiwa, kepribadian, budi pekerti, perilaku, personalitas, sifat, tabiat, temperamen, dan watak.

Jadi bisa disimpulkan bahwa karakter itu erat kaitannya dengan personality. Seseorang bisa dikatakan berkarakter apabila tingkah lakunya sesuai dengan kaidah moral. Individu yang berkarakter baik atau unggul adalah seseorang yang berusaha melakukan hal-hal yang terbaik terhadap Tuhan Yang Maha Esa, dirinya, lingkungan, bangsa dan negara, serta dunia internasional pada umunya dengan mengoptimalkan potensi (pengetahuan) dirinya dan disertai dengan kesadaran, emosi dan motivasinya (perasaanya). Karakter itu lebih bersifat spontanitas maksudnya dalam bersikap atau melakukan perbuatan telah menyatu dalam diri manusia sehingga ketika muncul tidak perlu difikirkan lagi.

\section{Pendidikan Karakter}

Pendidikan adalah proses internalisasi nilai budaya ke dalam diri seseorang dan masyarakat sehingga orang dan masyarakat menjadi beradap. Pendidikan bukan hanya merupakan sarana menstransfer ilmu pengetahuan saja, tetapi lebih luas lagi yakni sebagai sarana pembudayaan dan penyaluran nilai (enkulturasi dan sosialisasi). Pendidikan karakter adalah suatu sistem penanaman nilai-nilai karakter kepada warga sekolah yang meliputi komponen pengetahuan, kesadaran atau 


\section{Cucum Novianti}

kemauan, dan tindakan untuk melaksanakan nilai-nilai tersebut. Pendidikan karakter ini berkutat pada empat hal yaitu olah hati, olah pikir, olah rasa dan olah raga. Olah hati yang dimaksud adalah berkata, bersikap, dan berperilaku jujur. Olah pikir artinya cerdas yang selalu merasa membutuhkan pengetahuan. Olah rasa artinya memilki cita-cita. Sedang olah raga artinya enjaga kesehatan di tengahtengah menggapai cita-cita tersebut.

Pendidikan karakter dimaknai sebagai pendidikan yang mengembangkan nilai-nilai budaya dan karakter bangsa pada diri peserta didik sehingga mereka memiliki nilai dan karakter sebagai karakter dirinya, menerapkan nilai-nilai tersebut dalam kehidupan dirinya, sebagai anggota masyarakat, dan warga negara yang religius, nasionalis, produktif dan kreatif (Puskur, 2010). Menurut T. Ramli (2003), pendidikan karakter memiliki esensi dan makna yang sama dengan pendidikan moral dan pendidikan akhlak. Tujuannya adalah membentuk pribadi anak supaya menjadi manusia, warga masyarakat dan warga negara yang baik.

\section{Fungsi dari pendidikan karakter}

Pendidikan karakter adalah pendidikan budi pekerti plus, yaitu yang melibatkan aspek pengetahuan (kognitif), sikap dan perasaan (afektif), dan tindakan (aksi). Tanpa ketiga aspek ini maka pendidikan karakter tidak akan efektif. Dengan pendidikan karakter yang diterapkan secara sistematis dan berkelanjutan maka seorang anak akan menjadi cerdas emosinya. Kecerdasan emosi ini adalah bekal dalam mempersiapkan anak menyongsong masa depan karena seseorang akan lebih mudah dan berhasil menghadapi segala macam tantangan hidup termasuk tantangan untuk berhasil secara akademis.

Fungsi dari pendidikan karakter dan budaya bangsa menurut Puskur (2010) adalah sebagai berikut :

1. Pengembangan; pengembangan potensi peserta didik untuk menjadi pribadi yang berperilaku baik,

2. Perbaikan; memperkuat kiprah pendidikan nasional untuk bertanggung jawab dalam pengembangan potensi peserta didik yang lebih bermartabat

3. Penyaring; untuk menyaring budaya bangsa sendiri dan budaya bangsa lain yang tidak sesuai dengan nilai budaya dan karakter budaya yang bermartabat 


\section{Tujuan Pendidikan Karakter}

Mengacu pada dasar falsafah bangsa, maka Pancasila sebagai kristalisasi nilai budaya bangsa Indonesia, harus tetap menjadi rujukan dalam menerapkan berbagai aktivitas kehidupan berbangsa dan bernegara termasuk di dalamnya baik aktivitas menata program dan menyelenggarakan pendidikan, maka sila-sila Pancasila merupakan nilai-nilai luhur bangsa Indonesia tetap merupakan pilar dalam mewujudkan proses penyelenggaraan pendidikan karakter. Dr. Ratna Megawangi pencetus karakter di Indonesia menyebutkan nilai-nilai karakter, diantaranya yaitu :

1. Cinta Tuhan dan kebenaran

2. Tanggung jawab, kedisiplinan dan kemandirian

3. Amanah

4. Hormat dan santun

5. Kasih sayang, kepedulian,dan kerja sama

6. Percaya diri, kreatif, dan pantang menyerah

7. Keadilan dan kepemimpinan

8. Baik dan rendah hati

9. Toleransi dan cinta damai

Pendidikan karakter bertujuan untuk meningkatkan mutu penyelenggaraan dan hasil pendidikan di sekolah yang mengarah pada pencapaian pembentukan karakter dan akhlak mulia peserta didik secara utuh, terpadu, seimbang, dan sesuai dengan standar kompetensi lulusan. Melalui pendidikan karakter diharapkan peserta didik mampu secara mandiri meningkatkan dan menggunakan pengetahuannya dalam mempersonalisasi nilai-nilai karakter dan akhlak mulia sehingga terwujud dalam perilaku sehari-hari.

Tujuan pendidikan karakter menurut Puskur (2010) yaitu sebagai berikut :

1. Mengembangkan potensi kalbu/nurani/ afektif peserta didik sebagai manusia dan warga negara yang memiliki nilai-nilai budaya dan karakter bangsa

2. Mengembangkan kebiasaan dan perilaku peserta didik yang terpuji dan sejalan dengan nilai-nilai universal dan tradisi budaya bangsa yang religius 
3. Menanamkan jiwa kepemimpinan dan tanggung jawab peserta didik sebagai generasi penerus bangsa

4. Mengembangkan kemampuan peserta didik menjadi manusia yang mandiri, kreatif dan berwawasan kebangsaan

5. Mengembangkan lingkungan kehidupan sekolah sebagai lingkungan belajar yang aman, jujur, penuh kreativitas dan persahabatan, serta rasa kebangsaan yang tinggi dan penuh kekuatan

\section{Hubungan antara Pendidikan Karakter dengan Kecerdasan dan Keberhasilan Akademik}

Pengertian karakter ini banyak dikaitkan dengan pengertian budi pekerti, akhlak mulia, moral, dan bahkan dengan kecerdasan ganda (multiple intelligence). Terkait dengan kecerdasan ganda, bahwa kecerdasan meliputi empat pilar saling terkait satu sama lain, yaitu kecerdasan intelektual, kecerdasan spiritual, kecerdasan emosional, dan kecerdasan sosial. Kecerdasan sosial sering disebut sebagai kecerdasan yang berdiri sendiri yang lebih disebut dengan pengertian cerdas pada umunya, dengan ukuran baku internasional yang dikenal dengan istilah IQ. Sementara kecerdasan yang lainnya belum atau tidak memiliki ukuran matematis sebagaimana kecerdasan intelektual. Kecerdasan di luar kecerdasan intelektual inilah yang lebih dekat dengan pengertian karakter pada umumnya. Dr. Martin Luther King tokoh spiritual kulit hitam di Amerika Serikat menyatakan bahwa pendidikan bertujuan untuk melahirkan insan cerdas secara komprehensif, menyeluruh dan berkarakter kuat.

Adakah hubungan antara karakter dengan keberhasilan akademik?

Sebuah buku yang baru terbit berjudul Emotional Intelligence and School Success (Joseph Zins, et.al, 2001) mengkompilasikan berbagai hasil penelitian tentang pengaruh positif kecerdasan emosi anak terhadap keberhasilan di sekolah. Faktorfaktor yang menyebabkan kurang berhasil di bidang akademik bukan hanya terketak pada kecerdasan otak, tetapi pada masalah karakter, yaitu rasa percaya diri, kemampuan bekerja sama, kemampuan bergaul, kemampuan berkonsentrasi, rasa empati, dan kemapuan berkomunikasi. Hal ini sesuai dengan pendapat Daniel Goleman tentang keberhasilan seseorang di masyarakat, ternyata 80\% dipengaruhi 


\section{Cucum Novianti}

oleh kecerdasan emosi dan hanya 20\% ditentukan oleh kecerdasan otak (IQ). Anakanak yang mempunyai masalah dalam kecerdasan emosinya akan mengalami kesulitan dalam belajar, bergaul dan tidak dapat mengontrol emosinya. Anak-anak yang bermasalah ini sudah dapat dilihat sejak usia pra-sekolah, dan bila tidak cepat ditangani maka akan terbawa sampai usia dewasa. Sebaliknya para remaja yang berkarakter atau mempunyai kecerdasan emosi yang tinggi akan terhindar dari masalah-masalah umum yang dihadapi oleh para remaja misalnya tawuran, narkoba, miras dan sebagainya.

\section{Peran lembaga Pendidikan Anak Usia Dini dalam mengembangkan dan menanamkan pendidikan karakter}

Lembaga pendidikan mempunyai peran yang sangat penting dalam upaya untuk membentuk karakter, walaupun dasar dari pendidikan karakter adalah di dalam lingkungan keluarga. Apabila seorang anak memperoleh pendidikan karakter yang baik dalam keluarga, maka anak tersebut selanjutnya akan berkarakter baik pula. Namun banyak orang tua yang hanya mementingkan aspek kecerdasan otak daripada pendidikan karakter.

Peran lembaga pendidikan diibaratkan sebagai "mesin" untuk mencetak sumber daya manusia yang berkarakter. Lembaga pendidikan menjadi "bengkel" bagi perbaikan moralitas bangsa yang terkikis oleh dampak negatif modernisasi. Pendidikan dituntut berperan aktif sebagai agen perubahan.

8. Implementasi pendidikan karakter khususnya pada Pendidikan Anak Usia Dini

Pendidikan karakter adalah suatu sistem penanaan nilai-nilai karaker kepada warga sekolah yang meliputi komponen pengetahuan, kecerdasan atau kemauan dan tindakan untuk melaksanakan nilai-nilai tersebut, baik terhadap Tuhan Yang Maha Esa, diri sendiri, sesama, lingkungan maupun kebangsaaan sehingga menjadi manusia insan kamil. Dalam pendidikan karakter di sekolah, semua komponen harus dilibatkan termasuk komponen itu sendiri yaitu kurikulum, prose pembelajaran dan penilaian, kualitas hubungan, penanganan atau pengelolaan mata pelajaran, pengelolaan sekolah, pelaksanaan aktivitas atau kegiatan ko-kurikuler, pemberdayaan sarana dan prasarana, pembiayaan dan etos kerja seluruh warga dan lingkungan sekolah. 
Selam ini pendidikan dalam lingkungan keluarga belum memberikan kontribusi berarti dalam mendukung pencapaian kompetensi dan pembentukan karakter peserta didik. Kesibukan orang tua yang relatif tinggi, kurangnya pemahaman orang tua dalam mendidik anak, pengaruh pergaulan luar, dan pengaruh media elektronik ditengarai bisa mempengaruhi perkembangan dan pencapaian hasil belajar peserta didik. Salah satu alternatif untuk mengatasi permasalahn tersebut yaitu melalui pendidikan karakter terpadu, yaitu memadukan dan mengoptimalkan kegiatan pendidikan informal lingkungan keluarga dengan pendidikan formal di sekolah.

Pendidikan karakter di sekolah juga sangat terkait dengan manajemen atau pengelolaan sekolah. Pengelolaan yang dimaksud adalah bagaimana pendidikan karakter direncanakan, dilaksanakan, dan dikendalikan dalam kegiatan-kegiatan pendidikan di sekolah secara memadai. Pengelolaan tersebut meliputi nilai yang perlu ditanamkan, muatan kurikulum, pembelajaran, penilaian, pendidik dan tenaga kependidikan.

Dalam menerapkan pendidikan karakter di sekolah terdapat empat model yaitu :

\section{1. Model otonom}

Memposisikan pendidikan karakter sebagai mata pelajaran tersendiri yang menghendaki adanya rumusan yang jelas tentang standar isi, kompetensi dasar, silabus, rencana pembelajaran, bahan ajar, metodologi dan evaluasi pembelajaran.

\section{2. Model integrasi}

Mengintergasikan pendidikan karakter dengan seluruh bidang pengembangan ditepuh dengan paradigma bahwa semua guru adalah pengajar karakter. Pada tingkat PAUD terdapat lima bidang pengembangan yang dapat diintergasikan dengan pendidikan karakter, yaitu bidang pengembangan Nilai Agama dan Moral, bidang pengembangan Sosial, Emosional dan Kemandirian, bidang pengembangan Bahasa, bidang pengembangan Kognitif, bidang pengembangan Fisik Motorik. Materi pembelajaran yang berkaitan dengan norma atau nilai-nilai perlu dikembangkan dan dikaitkan dengan konteks kehidupan sehari-hari. Dengan demikian pembelajaran nilai karakter tidak hanya pada tataran kognitif tetapi internalisasi dan pengamalan nyata dalam kehidupan sehari-hari. 


\section{3. Model suplemen}

Pendidikan karakter juga dilaksanakan di luar jam sekolah yang mana dapat ditempuh dengan dua cara yaitu melaui kegiatan ekstrakurikuler dan melalui kegiatan kemitraan dengan lembaga lain yang memiilki kapabilitas dalam pembinaan karakter.

Kegiatan ekstrakurikuler merupakan salah satu media yang efektif untuk pembinaan karakter dan peningkatan mutu akademik peserta didik. Kegiatan ekstrakurikuler dapat membantu pengembangan peserta didik sesuai kebutuhan, potensi, bakat dan minat. Selain itu dengan kegiatan ini diharapkan dapat mengembangkan kemampuan dan rasa tanggung jawab, sosial, serta potensi peserta didik.

\section{4. Model kolaborasi}

Merupakan kolaborasi dari semua model dan merupakan upaya untuk mengoptimalkan kelebihan setiap model dan menutupi kekurangan masing-masing pada sisi lain.

Selain model penerapan pendidikan karakter di sekolah, terdapat juga alternatif pembelajaran pendidikan karakter di sekolah yaitu :

\section{1. Tahap pembelajaran}

Dalam pendidikna karakter menuju pada terbentuknya akhlak mulia dalam diri maka terdapat tiga tahapan yang harus dilalui yaitu :

a) Moral knowing, bertujuan agar peserta didik mampu membedakan antara nilai karakter mulia dengan karakter tercela

b) Moral loving, bertujuan untuk menubuhkan rasa cinta dan rasa membutuhkan terhadap karakter mulia

c) Moral doing, merupakan puncak keberhasilan pendidikan karakter yang mana peserta didik mempraktikkan karakter mulia tersebut dalam kehidupan sehari-hari

\section{2. CTL Sebagai Alternatif Dalam Pendidikan Karakter}

Cotextual Teaching Learning adalah proses pendidikan yang mana mengaitkan pebelajaran dengan pengalaman nyata peserta didik. Peserta didik diharapkan belajar langsung dengan mencari dan menggabungkan informasi secara aktif dari masyarakat lalu menggabungkannya untuk alasan tertentu. Selanjutnya peserta didik dirangsang untuk mengajukan pertanyaan seputar karakter. Pertanyaan ini 


\section{Cucum Novianti}

akan membantu peserta didik untuk menemukan kaitan antara pelajaran di kelas dengan situasi yang mereka alami baik di sekolah, rumah maupun masyarakat. Dalam upaya menguatkan kesadaran berkarakter positif maka peserta didik perlu dibawa ke dalam pengalaman hidup bersama orang lain dalam situasi yang sangat berbeda dari kehidupan sehari-harinya.

Di sekolah pendidikan karakter adalah integrated dalam berbagai disiplin ilmu. Lalu bagaimana pendidikan karakter dapat diberikan dan disampaikan secara efektif kepada peserta didik? Berikut adalah strategi efektif dalam melakukan pembelajaran pembentukan karakter yaitu :

\section{a) Involve the parents (libatkan orang tua)}

Libatkan orang tua dalam kegiatan sekolah. Selain itu selalu melakukan komunikasi yang intensif dan terbuka demi membangun tegaknya moral anak.

\section{b) Role playing (bermain peran)}

Peserta didik terutama anak usia dini sangat suka sekali bermain peran. Guru hendaknya memberikan kesepatan pada peserta didik untuk memerankan peranperan tertentu

\section{c) Introduce reading good books (mengenalkan macam- macam buku bagus)}

Lupakan lembar kegiatan siswa untuk sementara waktu. Sudah waktunya para peserta didik mengeksplorasi keajaiban membaca. Buku adalah pusat kekuatan nilai. Banyak sekali nilai yang tertanam melalui membaca dongeng.

\section{d) Play games (bermain game)}

Melalui permainan game kita dapat menanamkan pentingnya rasa tanggung jawab, dan kerja sam dengan tim.

\section{e) Praise and recognition (pujian dan pengakuan)}

Memperkuat setiap perbuatan baik dengan memberikan pujian dan pengakuan sebagai bentuk motivasi.

\section{KESIMPULAN}

Apapun strategi yang dilakukan guru, yang terpenting yaitu selalu menunjukkna contoh yang baik. Kita harus ingat bahwa peserta didik belajar sesuatu melalui imitasi. Jika mereka bisa meniru cara orang tua/ guru berbicara, berapa banyak lagi nilai yang bisa orang dan guru pancarkan? Disamping itun juga 


\section{Cucum Novianti}

di sekolah adanya dukungan-dukungan penciptaan lingkungan dengan memampang slogan-slogan yang berisi ajakan dan anjuran untuk selalu berkarakter mulia.

\section{REFERENCES}

Abdul Munir Mulkhan, Paradigma Intelektual Muslim: Pengantar Filsafat Pendidikan dan Dakwah. Yogyakarta: SI Press,1992

Abdurrahman Mas'ud,Menggagas Format Pendidikan Nondikotomik, Jogjakarta;Gama Media,2002

Ensiklopedi Islam Jilid 1 ,Jakarta;Ikhtiar Baru Van Hoeve,2001 Ensiklopedi Islam Jilid 3 ,Jakarta;Ikhtiar Baru Van Hoeve,2001

Harun Nasution, Muhammad Abduh dan Teologi Rasional Mu'tazilah, Jakarta: UI-Press, 1987 Harun Nasution,Pembaharuan dalam Islam Sejarah Pemikiran dan Gerakan ,Jakarta; Bulan Bintang,1975

Harun Nasution, Islam Ditinjau dari Berbagai Aspek Jakarta: UI Press, 1974

Husayn Ahmad Amin,Seratus Tokoh dalam Sejarah Islam,Bandung; Remaja Rosdakarya,2001

Mahyuddin Syaf dan A. Bakar Usman, Ilmu dan Peradaban. Bandung: Diponegoro, 1978

Rusni,Kemuhammadiyahan,Surakarta;Majlis Dikdasmen Pimpinan Muhammadiyah Kota Surakarta,1994

Syafi'i Ma'arif, Peta Intelektual Muslim Indonesia, Bandung: Mizan, 1994

Syekh Muhammad Abduh,Risalah Tauhid,Jakarta ; Bulan Bintang 1975

Toto Suharto, Filsafat Pendidikan Islam, Yogyakarta: Arruzz, 2006

Amier Daien Indarkusuma.. Pengantar Ilmu Pendidikan. Surabaya: Usaha Nasional. 2003

Kementerian Agama RI. 2011. Al-Qur'an dan Terjemahannya. Surabaya: Optima

Undang-Undang RI No. 20 Tahun. 2003. Sistem Pendidikan Nasional. Jakarta: Citra Umbara http://akhmadsudrajat.wordpress.com/2010/08/20/pendidikan-karakter-di-smp/ di akses tanggal 18-06-17

Mochtar Buchori, Akhmad Sudrajat, "pendidikan-karakter-di-smp"

http://.wordpress.com/2010/08/20//Diunduh tanggal 18-06-17. 2007

Akhmad sudrajat, "pendidikan-karakter-di-smp"http://.wordpress.com/2010/08/20// Diunduh tanggal 19-06-17

Ali Ibrahim Akbar, 2000, Akhmad sudrajat, "pendidikan-karakter-di-

smp"http://.wordpress.com/2010/08/20//Diunduh tanggal 19-06-17.

Akhmad sudrajat, "pendidikan-karakter-di-smp"http://.wordpress.com/2010/08/20//Diunduh tanggal 20-06-17.

Mar'at.. Sikap Manusia Perubahan Serta Pengukurannya. Bandung: Psikologi. 2000 